\title{
Nd-YAGレーザーによる実験的脳深部照射 急性実験之慢性実験の比較 \\ Experimental Study of Deep Brain Irradiation with Nd-YAG Laser Conparison between Acute Lesion and Chronic Lesion
}

○藤鼠一郎, 堺 常雄, ${ }^{1}$ 龍 浩志, 植村研一, ${ }^{2}$ 中島正二, 橋本大定 ${ }^{4}$

O Ichiro Fujishima, ${ }^{1}$ Tsuneo Sakai, Hiroshi Ryu, Kenichi Uemura, Syoji Nakajima, ${ }^{3}$ Daijo Hashimoto.

1. 聖隷三方原病院脳神経外科，2. 浜松医科大学脳神経外科，

3. 富士宮汸立病院脳神経外科，4。東京大学第 2 外科

1. Department of Neurosurgery, The Seirei Mikatabara General Hospital.

2. Department of Neurosurgery, Hamamatsu University School of Medicine.

3. Department of Neurosurgery, Fujinomiya City Hospital.

4.2nd Department of Surgrery, Uuniversity of Tokyo.

\section{A bstruct}

Deep brain irradiation with Nd-YAG Laser was experimentally studied in 36 adult cats. The quartz fiber of Nd-YAG Laser with a convex tip was inserted into the thalamus and a spheric lesion was successfully made.

(1) Just after irradiation in acute stage four distinct zones (vaporized, carbonized, necrotized and edematous zones) were identified and no bleeding was seen in any zone.

(2) 12 hours later edema extended along the white matter.

(3) 24 hours later edema extended widely along the white matter and petecheal hemorrhage was seen in the necrotized zone.

(4) 48 hours later: no changes were seen.

(5) 2 weeks later: gliosis containing macrophages were seen around the necrotized zone and edma was subsiding.

(6) 4 weeks later: vaporized cavity and gliosis with many macrophages were seen.

Key words : Nd-YAG Laser, Laser lesion, Brain tumor, Deep brain irradiation.

〈はじめに> 外科的治療の困難な深部脑〈方法〉成猫 36 ル(体重 $2.3 \mathrm{~kg}-4.7 \mathrm{~kg}$ )

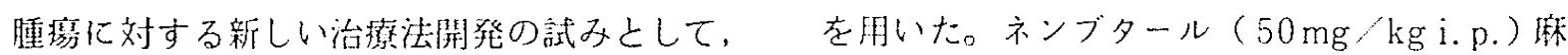

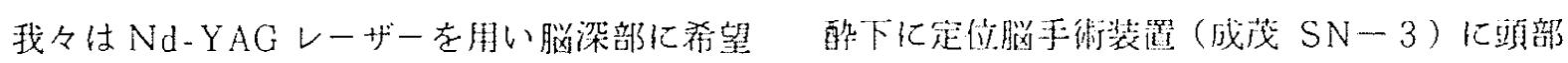

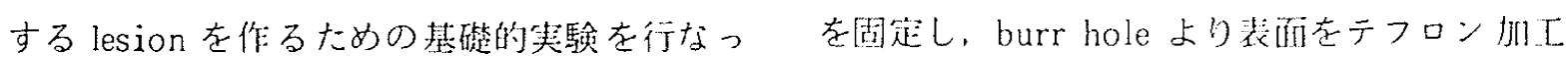
ている。”回は急性奏験と慢性荚験の lesion したステンレスのガイドチューブを介して， の比較を行なった。

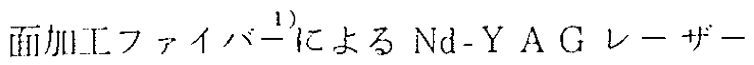




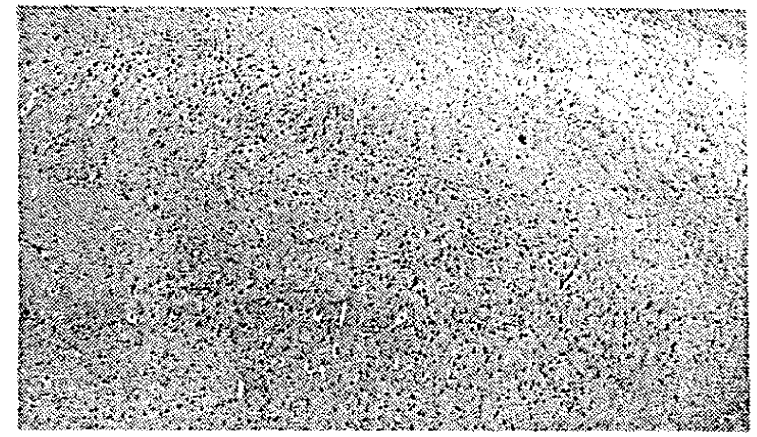

図 1. 照射 12 時間後 H. E. × 100

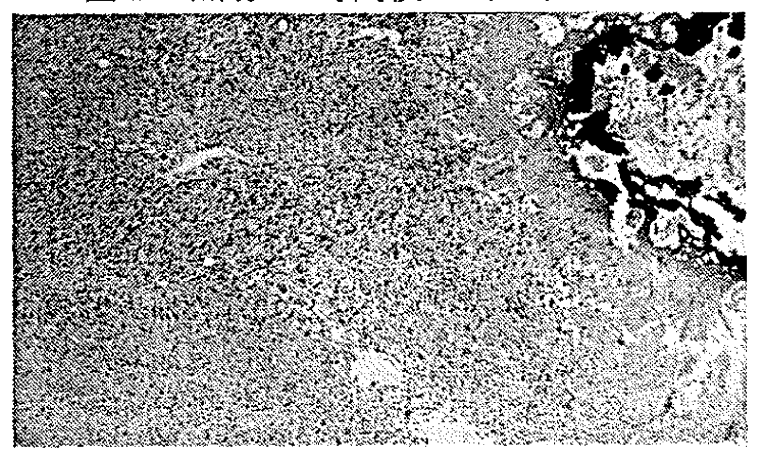

図 3. 照射 2 週間後 H. E. $\times 100$
(Medilas YAGレーザー) による 7 watt, 1 min. の持続的照射を行なった。照射後は経時 的に屠殺し，10\%ホルマリンで固定した。2週 間後にファイバーの㨉入方向に沿って脳に割面 を入れ，脳の肉眼的観察を行なった後，パラフ ィン包埋し H. E. 染色にて光顕的観察を行な いlesionの变化を追跡した。

く結 果〉 凸面加エファイバーによるlesion はほほ球形で（1照射直後の lesionは (1)空洞 層 (2)炭化層 (3)壊死層 (4)浮腫層の4 層加区 別され、レーザー照射に伴うと思われる出向は 見られなかった。(2)12 時間後では白質に沿っ て浮腫が広がり始めた(図 1)。(3)24時間後, 浮腫は白質に沿って広範化拡大し, 壊死層と浮 腫層の境界付近では点状出血がみられた（図一 2)。(4) 48 時間後，浮腫層の範囲，点状出血の 状態は24時間と殆んど变化がなかった。(5)2

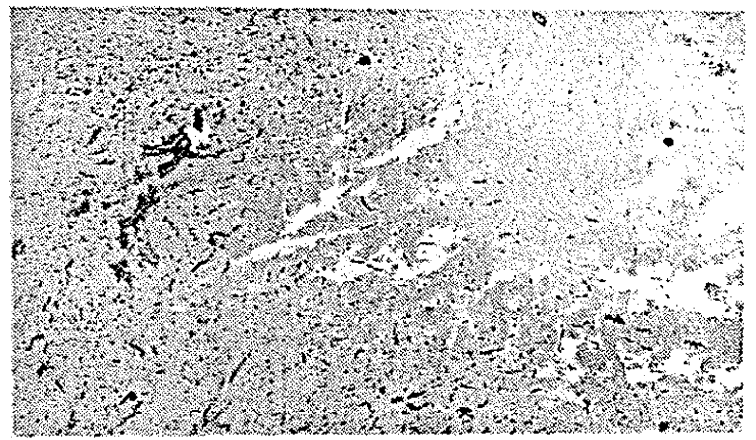

図 2. 照射 24 時間後 H.E. × 100

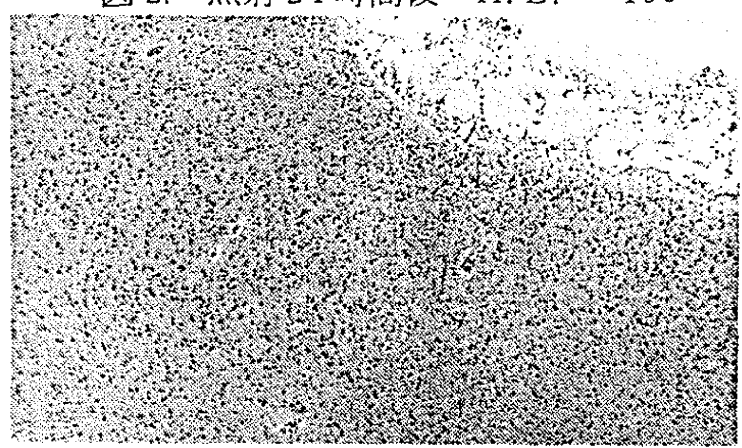

図 4. 照射 4 週間㣪 H.E. $\times 100$

週間後，壊死層中心にマクロファージの出現と gliosis がみられ，浮腫層は殆んど消失した (図一3)。(6)4 週間後、マクロファージはまだ 多数みられるが, lesion は空洞と gliosis を残 すのみとなった（図一 4 )。

〈考 按〉 Nd-YAGレーザーは凝固，止 血作用にすぐれ，細小石英ファイバーで導光で きるため扱いやすく，脳深部への誘導も容易で ある。我々の方法を用いれば從来外科的治療の 困難であった墚部脳腫癁を中心から，凝固，蒸 散できるため大いに治療効果が期待できるが， 照射徯に生じる浮腫に十分留意する必要がある と思われた。

<結 語〉 Nd-YAG レーザー照射後の lesion には術後 24 時間〜 48時間に白質に沿っ て広がる浮腫及び壊死層に点状出向が生じ，乙 れが急性実験と異る点であっだ。
1）藤島一郎, 龍 浩志他：Nd-Y A Gレーザ 一による脳深部照射の基碟的実験

Neurol Med Chir (Tokyo) 26,621-627, 1986.
2) BURKE LE etc; Neodymium-YAG Laser in Medicine and Surgery. New York, Elsenier. 1983. $282 \mathrm{P}$ 